\title{
Konfigurasi Fonem pada Leksikon Peralatan Rumah Tangga Tradisional yang Memiliki Kesamaan Medan Makna
}

\author{
M. Suryadi \\ Fakultas Ilmu Budaya, Universitas Diponegoro \\ mssuryadi07@gmail.com
}

\begin{abstract}
The aim of this research is to describe the phoneme configuration which is located in the ultima position within the lexicon of traditional household appliances. The phoneme configuration has nuances that mean local wisdom and social intelligence of Javanese ancestors. This type of research is descriptive-qualitative. The research locus is in Pati regency. Data collection methods used were observation and in-depth interviews. The data analysis method used is the distributional method: which is supported by the sorting and comparison techniques. The padan method is used to analyze lexical semantic elements. The findings of the research show that the configuration of the phoneme lexicon of traditional household appliances in the ultima position has a semantic meaning, a philosophical value and a non-arbiteric meaning. The philosophical value is inherent in the configuration of the phoneme lexicon in the ultima position. Non-arbiter forms occur due to messages attached to phoneme configurations in the lexicon.
\end{abstract}

Keywords: Configuration; household appliances; lexicon; phonemes; traditional.

\section{Intisari}

Penelitian ini memiliki tujuan untuk mendeskripsikan konfigurasi fonem posisi ultima pada leksikon peralatan rumah tangga tradisional. Konfigurasi fonem memiliki nuansa arti yang mencerminkan kearifan local dan kecerdasan sosial leluhur Jawa. Jenis penelitian deskriptifkualitatif. Lokus penelitian di wilayah Kabupaten Pati. Metode pengumpulan data yang digunakan observasi dan wawancara mendalam. Metode analisis data memanfaatkan metode agih dengan teknik pilah dan teknik banding. Metode padan dimanfaatkan untuk menganalisis unsur semantik leksikal. Hasil temuan penelitian menunjukkan bahwa konfigurasi fonem yang tersusun dalam leksikon peralatan rumah tangga tradisional memiliki tautan arti semedan makna yang bersifat filosofis dan bersifat non-arbiter. Nilai filosofis melekat konfigurasi urutan fonem leksikon pada posisi ultima. Bentuk nonarbiter terjadi akibat pesan yang melekat pada konfigurasi fonem dalam leksikon.

Kata kunci: Fonem; konfigurasi; leksikon; peralatan rumah tangga; tradisional.

\section{Pendahuluan}

Bahasa sangat lekat dengan pikiran, apa yang dituturkan kerapkali mencerminkan apa yang dipikirkannya. Bahasa yang dituturkan seseorang sebagai cermin bagaimana sebenarnya berpikir terhadap realita yang dihadapinya (cf. Trager, Whorf, and Carroll 1957). Kenyataan 
yang dihadapinya, baik sebagai pengalam sendiri maupun pengamat membentuk perilaku dalam diri manusia atau masyarakat penggunanya. Perilaku dan bentuk tuturannya pun tidaka dilepaskan dengan latar belakang kultur yang membangun diri manusia atau masyarakat itu sendiri. Budaya dan perilaku masyarakat sebuah kesatuan yang tidak dapat dipisahkan. Dengan demikian bahasa dapat dikatakan sebagai identitas penggunanya, identitas pola pikirnya, dan sekaligus sebagai identitas bagi budayanya (Santoso 2017).

Bahasa Jawa tidak dapat dilepaskan dengan budaya Jawa. Budaya Jawa tersimpan dalam identitas leksikonnya, setiap leksikon Jawa akan mencerminkan sejarah bahkan etimologinya. Leksikon Jawa itupun manakala ditelusuri etimologinya berasal dari bahasa Sanskerta javadvipa bila diurai/direkonstruksi dari kata dvipa 'pulau' dan java 'jelai atau bijibijian'. Javadvipa memiliki arti pulau yang subur penuh dengan banyak tanaman padi atau sebagai lumbung padi. Demikian hebatnya kandungkan kata-kata dalam bahasa Jawa yang penuh dengan etimologi, budaya, dan filosofi.

Munculnya nilai-nilai filosofi, budaya, dan kekuatan semantik tidak lepas dengan konfigurasi fonem yang menyusun pada leksikon tersebut (Bergounioux 2016). Fonemfonem berkonfigurasi dalam setiap leksikon memiliki maksud tertentu tidak semena-mena. Jadi fungsi fonem tidak sekedar sebagai satuan terkecil yang mampu membedakan makna, namun memiliki fungsi menguatkan arti dengan bentukan-bentukan baru sesuai dengan kekuatan konfigurasi fonem itu sendiri ("Karl Bühler et La Physionomie Acoustique Des Mots: Les Occasions Manqufies de La Phonologie" 2012). Kekayaan konfigurasi fonem dalam varian leksikon Jawa sangat melimpah, terutama pada leksikon-leksikon peralatan rumah tangga yang tradisional, misal pada leksikon wakul 'tempat nasi', sekul 'nasi', bakul 'penjual/bedagang atau tempat sayur', dan pikul 'alat untuk mengangkat barang dengan cara dipikul'. Bentukan kosakata tersebut tidak serta-merta atau arbiter namun bentukan yang memiliki alur yang dapat direkonstruksi dengan pola pemikiran konfigurasi fonemnya. Semua kajian fenomena tersebut, diperikan dalam rumusan masalah penelitian.

Adapun rumusan masalah yang diangkat dalam penelitian ini, sebagai berikut. (1) Bagaimana merunut konfigurasi fonem yang membangun leksikon peralatan rumah tangga tradisional yang memiliki arti semedan makna. (2) Bagaimana proses konfigurasi fonem dapat terjadi tanpa kearbiteran.

Berangkat dari dua rumusan masalah maka tujuan penelitian yang segayut adalah (1) Mendeskripsikan perilaku fonem yang memiliki fungsi ganda selain sebagai pembeda arti 
juga memiliki fungsi penguat arti dalam konfigurasinya pada konstruksi leksikon. (2) Mengungkap kearifan lokal dan kecerdasan sosial masyarakat Jawa bahwa identitas sebuah leksikon pada peralatan rumah dalam penetapannya mempertimbangkan multi aspek.

Untuk mencapai hasil yang optimal dan analisis yang tajam, diperlukan referensi sebagai penopang analisis sekaligus untuk mengukur kebaruan temuan hasil penelitian. Adapun beberapa sumber refensi yang dimanfaatkan dalam penelitian ini, sebagai berikut.

Antono et.al meneliti varian bahasa Jawa yang digunakan oleh penutur Jawa di Kabupaten Wonogiri. Fokus kajiannya pada unsur lingual fonologis dan leksikal saja. Hasil temuannya secara eksplisit bahwa terdapat sederet fonem purba yang masih dipertahankan dan sebagain varian leksikon pun masih dipertahankan (Antono, Zulaeha, and Baehaqie 2019). Penelitian ini memberikan abstraksi bahwa unsur lingual fonem dalam bahasa Jawa memiliki daya reliksitas yang cukup tinggi, berarti tugas fonem sebagai unsur pembangun fonem memiliki fungsi dalam pembeda arti. Namun dibalik substansi yang sebenarnya mengapa unsur-unsur fonem tersebut bila berkonfigurasi dapat membangun jumlah leksikon yang takterhingga belum tersentuh. Penelitian ini sebagai inspirasi bahwa fonem memiliki bentuk yang stabil dan reliksitas yang tinggi.

Teori dasar yang dimanfaatkan dalam penelitian ini adalah empat pikiran Brandstetter tentang konsep akar kata dalam bahasa-bahasa Melayu / bahasa Indonesia, konsep ini sangat terkenal walaupun usia teori sudah dapat dikatakan sangat tua, namun masih sangat relevan. Konsep yang paling populer adalah menawarkan perunutan sejumlah akar kata yang diturunkan dari urutan fonem-fonemnya (Brandstetter 1916) dan (Brandstetter 1957).

Pemanfaatan konfigurasi fonem dalam kata menggunakan teori yang dicetuskan oleh Trubeckoj, tokoh linguistik aliran Praha yang mengembangkan unsur fonem dalam pembentukan kata lebih bersifat fungsional (Vachek 2003). Lebih lanjut Trubetzkoj menyatakan fungsi kajian fonologi lebih eksakta dan dapat dijelaskan dengan fungsifungsinya melalui konfigurasi fonem dalam kata. Beberapa fungsi fonem yang diutarakan Trubetzkoj sebagai berikut. Konsep dasar fonem, kaidah penentuan sebuah fonem, klasifikasi oposisi fonem, dan konfigurasi fonem (Cairns, Trubetzkoy, and Baltaxe 1971).

Etika dan nilai filosofis masyarakat Jawa menjadi pegangan dalam mengkaji arti/makna kultural Jawa. Referensi yang digunakan sebagai salah satu pijakan terhadap pemaham budaya/kultural Jawa adalah Kosmologi Jawa Sebagai Landasan Filosofis Etika Lingkungan (Haryati 2017). Penelitian ini berpijak pada patron kosmologi Jawa. Kosmologi 
Jawa selalu menyeimbangkan hubungan antara manusia dengan alam, menyelaraskan dengan alam, sekaligus bagian dari alam dan berperan untuk kelestarian alam. Kajian ini mengispirasi bahwa setiap manusia Jawa dalam bertindak selalu menghindari terjadinya konflik dengan alam, setiap apa yang dilakukan dengan baik psikal maupun mental selalu menjaga keharmonisan dengan alam.

\section{Metode Penelitian}

Jenis penelitian ini adalah deskriptif kualitatif. Lokus penelitian area Jawa Pesisiran di Kabupaten Pati. Metode pengumpulan data menggunakan metode observasi dan metode wawancara terstruktur dan wawancara mendalam. Metode observasi digunakan untuk mendapatkan gambaran umum lokasi penelitian, objek penelitian, dan perwatakan umum adat/tradisi lokal. Metode wawancara terstruktur dipergunakan untuk memperoleh data atau informasi awal tentang seting informan berbudaya Jawa pesisir dan kemampuan lingual bertutur Jawa. Metode wawancara mendalam digunakan untuk memperdalam informasi yang diperoleh dari wawancara terstruktur. Teknik pemerolehan data metode ini menggunakan slip untuk per item pertanyaan yang dianggap membutuhkan informasi lebih mendalam dari aspek-aspek yang digali melalui wawancara terstruktur.

Metode analisis data yang digunakan adalah metode agih dan metode padan (Sudaryanto 1993). Penggunaan metode agih dengan memanfaatkan teknik pilah dan teknik subtitusi. Metode padan digunakan pada saat menganalisis nilai semantik yang berada di luar bahasa itu sendiri. Pada saat menganalisis data teori yang digunakan adalah mensinergiskan teori akar kata (Brandstetter 1916 dan 1957) dan teori konfigurasi fonem pada leksikon (Cairns, Trubetzkoy, and Baltaxe 1971). Kedua teori ini akan mempertajam analisis dalam mengkaji konfigurasi fonem dalam leksikon Jawa peralatan rumah tangga tradisonal.

\section{Hasil dan Pembahasan}

Kajian perihal konfigurasi fonem pada leksikon peralatan rumah tangga tradisional yang memiliki kesamaan medan makna terperinci atas beberapa subbab, hal ini dilakukan supaya pembahasan lebih sistematik dan terukur hasilnya. Adapun pembahasan kajian diperikan sebagai berikut.

\section{Kekayaan Leksikon Jawa pada Peralatan Rumah Tangga Tradisional}

Leksikon Jawa adalah sekumpulan kosakata yang dimiliki bahasa Jawa dengan segala variannya, baik yang produktif dalam penggunaanya maupun dalam posisi improduktif. 
Leksikon Jawa sebagai base atau dasar seseorang untuk dapat berbahasa Jawa. Semakin banyak penguasaan leksikon Jawa maka semakin baik seseorang akan bertutur Jawa. Dengan banyaknya penguasaan leksikon bahasa Jawa maka semakin leluasa penutur Jawa dalam memilih kata yang sesuai dan yang diinginkan.

Kekayaan leksikon bahasa Jawa dalam bentuk ngoko atau netral jumlah tak terbatas dan terus berkembang sesuai dinamika penuturnya. Leksikon bahasa karma termasuk di dalamnya karma inggil dan krama andhap jumlahnya sangat terbatas, keterbatasan atau bersurutnya jumlah kosakata karma dalam bahasa Jawa banyak faktornya, salah satu faktornya adalah sistem pewarisan ke generasi muda kurang optimal dan lingkup penggunaanya saat ini pada ranah terbatas.

Leksikon Jawa pada peralatan rumah tangga tradisional jumlahnya sangat terbatas, bahkan beberapa kosakatanya sudah mulai hilang dan tidak dikenali lagi. Surut dan hilangnya kosakata peralatan rumah tangga tradisional disebabkan oleh beberapa faktor, faktor utama atau faktor yang dominan berada di luar bahasa itu sendiri (ektra lingual). Faktra ektra lingual yang menyebabkan surut dan hilangnya kosakata peralatan tradisinal, sebagai berikut.

a. Era milenial atau era revolusi industry 4.0 adalah sebab paling dominan. Era ini fungsi pawon 'dapur tradisional' sudah digantikan dapur modern. Pawan atau papane barang kanga won 'tempat barang-barang yang kotor' sudah digantikan dengan dapur modern yang berisi peralatan modern, yang semua ditampilkan alat-alat dapur yang futuristic.

b. Perilaku bentuk makanan instan atau cepat saji mulai menggeser penggunaan alat-alat dapur tradisional. Alat-alat dapur tradisional yang dalam penanganan dan pengolahannya membutuhkan waktu dan seni kenikmatan mulai ditinggalkan. Fenomena ini terjadi karena kehidupan era milenial menginginkan serba cepat dan berburu waktu.

c. Peralatan tradisional yang berbahan alam mulai digantikan dengan berbahan plastik atau atom. Disamping disebabkan juga fator alam, yakni perajin alat-alat rumah tangga tradisional tidak diwariskan oleh generasi berikutnya.

Teriring perkembangan zaman yang saat ini sudah mencapai era 5.0 maka harus ada upaya pelestarian peralatan rumah tradisional, baik dalam upaya dokumentasian bentuk lingual nama-nama peralatan rumah tangga tradisonal maupun pelestarian psikal barangbarang peralatan rumah tangga tradisonal. Misal dengan modernisasi bentuk visual wakul 
'tempat nasi', cedhing 'tempat air bersih', glodog 'tempat penyimpanan beras', tampah 'tempat mengurai beras atau bahan makanan', dan kendhil 'tempat air minum'.

\section{Nilai-nilai Filosofi Leksikon Peralatan Rumah Tangga}

Proses pembuatan barang-barang alat-alat rumah tangga tradisional dilakukan oleh para leluhur Jawa yang memiliki keahlian khusus. Peralatan berbahan kayu dikerjakan oleh Undhagi. Perkakas berbahan batu dikerjakan oleh jlagara. Perkakas berbahan besi dikerjakan oleh pandhe, Perkakas berbahan tembaga dikerjakan oleh sayang, dan Perkakas berbahan tanah dikerjakan oleh pengrajin gerabah. Perkakas berbahan kuningan dikerjakan oleh gemblak. Menelusuri pembuatan peralatan rumah tangga tradisional yang dilakukakan oleh ahlinya (sesuai bidang keahliannya), maka hasil pembuatannya disamping memiliki kualitas juga memiliki nilai-nilai filosofi. Beberapa nilai filosofi yang masih melekat dengan peralatan rumah tangga tradisional, yakni sebagai berikut.

Kendhil peralatan rumah tangga tradisional yang memiliki nilai filosofi manejemen atau pengaturan ekonomi. Dalam filosofi Jawa kerapkali ditemukan ungkapan sebagai berikut.

a. Ati-ati yen uwis bebrayan aja nganti nggoling kendhile 'hati-hati bila sudah berkeluarga dijaga jangan sampai terpuruk kehidupannya'

b. Bojoku kerjo mung sakdermo kanggo njejegke kendhil. 'suamiku bekerja cukup untuk memenuhi kebutuan keluarga'

c. Mergawe sing temen kanggo ngebaki kendhile. 'bekerja yang sungguh-sungguh supaya kebutuhan keluarga dapat terpenuhi'

Ungkapan tersebut memberikan potret bahwa parameter kecukupan keluarga Jawa adalah memenuhi kebutuhan pokok keluarga yang dilambangkan dengan air kehidupan yang ditempatkan ditempatkan di kendhil 'tempat air minum'. Secara psikal wujud bangunan kendhil mencerminkan manejemen yang handal, yakni ada tiga kriteria: (1) pemasukkan, (2) penyimpanan, dan (3) pengeluaran. Konsep pemasukan yang dilambangkan dengan kepala kendhil. Kepala khendil memiliki lubang yang besar, nilai filosofinya adalah hasil kerja/pemasukkan untuk keluarga harus lebih banyak atau lebih besar. Konsep penyimpanan dilambangkan dengan tubuh kendhil yang besar, nilai filosofisnya bahwa manusia harus pandai menabung atau menyimpan hasil pekerjaannya. Konsep pengeluaran yang dilambangkan mulut kendhil dengan lubang yang kecil, nilai filosofisnya adalah semua pengeluaran dalam rumah tangga harus sekecil mungkin atau sehamat mungkin. Manakala 
nilai filosofis kendhil diterapkan manusia Jawa maka kehidupan keluarga akan mencapai kebahagian dan kecukupan. Tidak akan terjadi nggoling kendhile 'terpuruk kehidupan keluarganya'.

Enthong adalah alat perkakas rumah tangga tradisional yang berbahan dasar kayu dan atau bathok kelapa. Enthong 'sendok nasi' memiliki nilai filosofis cukup takarannya, tidak mau berlebih-lebihan. Takaran enthong sudah didesain dengan ukuran lambung manusia, yakni manakala makan cukup satu takaran saja artinnya manusia Jawa akan berhenti makan sebelum kenyang. Ada ungkapan yang mencerminkan pola kesederhanaan masyarakat Jawa yakni: aja pijer mangan nendra 'jangan selalu mementingkan makan dan tidur saja' dan sudanen dhahar lan guling 'kurangilah nafsu makan dan tidurmu'. Kata mangan dan dhahar dapat disinonimkan dengan enthong, nilai filosofisnya tahanlah enthong 'sendok nasi' pada saat hidangan makan, yakni ukurlah sesuai takarannya. Selain itu enthong juga memiliki nilai filosofis keadilan sosial, yakni dengan mencukupkan takaran satu enthong maka semuanya akan terbagi atau terpenuhi, Nilai filosofi tersebut terungkap pada kalimat berikut.

a. Rong entong ora marahi lemu lan kuat. 'Dua takaran tidak menyebabkan orang menjadi gemuk dan kuat'

b. Entong siji iso kanggo sakbrayan. 'Bila masing-masing cukup satu takaran maka dapat digunakan untuk mencukupi kebutuahnnya'

c. Enteri bebrayan sing isih mambu enthong 'Berikan kiriman bila masih mengandung pertautan keluarga'

Tiga ungkapan dalam kalimat tersebut mencerminkan nilai filosofis kehidupan sosial bermayarakat dengan asas keadilan.

\section{Konfigurasi Fonem dalam Leksikon Jawa}

Fonem dikenal sebagai satuan lingual yang kongkrit, sekaligus sebagai satuan terkecil yang mampu membedakan makna. Fonem itu sendiri mampu membedakan makna bila dibandingkan dengan fonem lain, baik melalui banding, ganti, sisipan, maupun pelesapan (tergantung data). Namun apakah fonem itu sendiri (secara otonom) mempunyai arti atau makna? Lihat data berikut ini.

\section{Data 1: Fonem vokal /e/ bahasa Jawa}

\section{Bagan Analisis Sistem Konfigurasi Fonem Vokal}

\begin{tabular}{|lr|l|}
\hline $\begin{array}{l}\text { Posisi } \\
\text { fonem }\end{array}$ & $:$ & $\begin{array}{l}\text { fonem vokal /e/ terletak pada posisi madya depan, tidak bulat, dan semi } \\
\text { tertutup }\end{array}$ \\
\hline Fungsi & $:$ & Unsur lingual yang mampu membedakan arti pada satuan lingual yang lebih \\
\hline
\end{tabular}




\begin{tabular}{|c|c|c|c|c|}
\hline fonem & besar & & & \\
\hline \multirow{4}{*}{$\begin{array}{l}\text { Metode } \\
\text { Agih }\end{array}$} & \multicolumn{2}{|c|}{ Teknik ganti } & \multicolumn{2}{|c|}{ Teknik lesap } \\
\hline & Konfigurasi fonem & Gloss & Konfigurasi fonem & Gloss \\
\hline & r-a-m-e & 'ramai' & w-a-k-u-l-e & 'bakulnya' \\
\hline & r-a-m-i & 'benang' & w-a-k-u-l & 'ibu' \\
\hline Simpulan & \multicolumn{4}{|c|}{$\begin{array}{l}\text { 1. Fonem vokal /e/ secara mandiri tidak memiliki arti hanya sebuah } \\
\text { lambang bunyi saja } \\
\text { 2. Memiliki arti manakala sudah berkonfigurasi dengan fonem-fonem lain } \\
\text { untuk membentuk konfigurasi-konfigurasi baru berupa kata-kata }\end{array}$} \\
\hline
\end{tabular}

Sistem analisis konfigurasi fonem ini membuktikan bahwa satuan lingual fonem sebenarnya adalah simbol bunyi yang kongkrit dan memiliki ketetapan sistem dalam sebuah bahasa, termasuk dalam bahasa Jawa. Konfigurasi fonem tersebut juga terjadi dalam fonem konsonan, bukti konfigurasi dalam fonem konsonan dideskripsikan sebagai berikut.

\section{Data 2: Fonem konsonan /b/ bahasa Jawa}

\section{Bagan Analisis Sistem Konfigurasi Fonem Konsonan}

\begin{tabular}{|c|c|c|c|c|}
\hline Posisi fonem & \multicolumn{4}{|c|}{ fonem konsonan /b/ terletak pada bilabial, hambat, dan bersuara } \\
\hline Fungsi fonem & \multicolumn{4}{|c|}{$\begin{array}{l}\text { Unsur lingual yang mampu membedakan arti pada satuan lingual yang lebih } \\
\text { besar }\end{array}$} \\
\hline \multirow{4}{*}{ Metode Agih } & \multicolumn{4}{|c|}{ Teknik ganti } \\
\hline & Konfigurasi Fonem & Gloss & Konfigurasi Fonem & Gloss \\
\hline & b-a-k-u-l & $\begin{array}{l}\text { tempat } \\
\text { hasil bumi }\end{array}$ & b-e-s-e-k & $\begin{array}{l}\text { tempat } \\
\text { menyimpan } \\
\text { makanan' }\end{array}$ \\
\hline & w-a-k-u-1 & tempat nasi & s-e-s-e-k & $\begin{array}{l}\text { alat } \\
\text { penggoreng }\end{array}$ \\
\hline Simpulan & \multicolumn{4}{|c|}{$\begin{array}{l}\text { 3. Fonem vokal /e/ secara mandiri tidak memiliki arti hanya sebuah } \\
\text { lambang bunyi saja } \\
\text { 4. Memiliki arti manakala sudah berkonfigurasi dengan fonem-fonem lain } \\
\text { untuk membentuk konfigurasi-konfigurasi baru berupa kata-kata }\end{array}$} \\
\hline
\end{tabular}


Kedua bagan tersebut membuktikan bahwa konfigurasi fonem dalam pembentukan kata lebih bersifat fungsional (Cairns, Trubetzkoy, and Baltaxe 1971) ketimbang sebagai pembeda arti(Gani and Arsyad 2019).

\section{Rekonstruksi Fonem Leksikon Jawa Peralatan Rumah Tangga Tradisional}

Rekonstruksi fonem pada posisi ultima dilakukan sebagai penelitian pendahuluan untuk mengawali penelitian berikutnya yang mengkaji secara komprehensif konfigurasi fonem-fonem yang terdapat dalam bahasa Jawa.

Bahasa Jawa memiliki kecenderungan setiap katanya tersusun dua silabe, yakni silabe ultima dan penultima. Kekayaan varian pada dua silabe ini sangat melimpah, termasuk pada kosakata peralatan rumah tangga tradisioanal. Leksikon bersilabe dua dalam peralatan rumah tangga tradisional, antara lain:

\begin{tabular}{|l|l|l|l|l|}
\hline No & \multicolumn{1}{|c|}{ Gloss } & \multicolumn{1}{|c|}{$\begin{array}{c}\text { Perkakas } \\
\text { Dapur }\end{array}$} & \multicolumn{1}{|c|}{$\begin{array}{c}\text { Struktur } \\
\text { Silabe }\end{array}$} & \multicolumn{1}{|c|}{$\begin{array}{c}\text { Konfigurasi } \\
\text { Fonem }\end{array}$} \\
\hline 1 & tempat sayur & kuali & kua-li & k-u-a-l-i \\
\hline 2 & tempat air minum & kendhil & ke-ndhil & k-e-Nd-i-l \\
\hline 3 & $\begin{array}{l}\text { tempat menggerus } \\
\text { bahan/sambal }\end{array}$ & cowek & co-wek & c-o-w-e-k \\
\hline 4 & tutup belangga & kekep & ce-kep & k-e-k-e-p \\
\hline 5 & tempat menyimpan air bersih & genthong & ge-nthong & g-e-Nt-o-n \\
\hline 6 & tempat menanak nasi & dandang & da-ndang & d-a-Nd-a-n \\
\hline 7 & belangga & kenceng & ke-nceng & k-e-Nc-e-n \\
\hline 8 & tempat penggorengan & wajan & wa-jan & w-a-j-a-n \\
\hline 9 & tempat merebus air/sayur & panci & pa-nci & p-a-Nc-i \\
\hline 10 & tempat air minum & ceret & ce-ret & c-e-r-e-t \\
\hline
\end{tabular}

Rekonstruksi fonem pada leksikon peralatatan rumah tangga tradisional dapat dibuktikan melalui analisis beberapa data, sebagai berikut.

\section{Data 3: kuali 'tempat sayur'}

Leksikon kuali $\rightarrow$ terdiri atas lima fonem yakni fonem konsonan:/k/ dan /l/ dan fonem vokal /u/, /a/,dan /i/. Setiap fonem memiliki potensi yang sama untuk berkonfigurasi. Kemungkinan konfigurasi yang terjadi sebagai berikut. 

a. k-u-a-l-i : kuali
b. u-a-1-i-k :*ualik
c. a-1-i-k-u : aliku
d. 1-i-k-u-a : *likua
e. i-k-u-a-l : *ikual
f. u-k-a-l-i : *ukali
g. u-a-k-l-i : *uakli
h. u-a-l-k-i : *ualki
i. u-a-i-l-k :*uailk
j. dan seterusnya

Banyak hipotesis yang ditawarkan oleh lima fonem: /k/, /l/, /u/, /a/, dan /i/, yang sistem konfigurasinya memanfaatkan teknik permutasi dan teknik linearitas, hanya dihasilkan dua leksikon yang memungkinkan diterima oleh penutur Jawa, yakni leksikon kuali dan aliku. Data ini memperlihatkan bahwa konfigurasi fonem dalam setiap kata disusun sedemikian rupa oleh kemampuan otak manusia melalui laguage acquisition device (LAD) yang dimiliki manusia sejak lahir. Konfigurasi fonem diciptakan oleh manusia dengan kesadaran laguage acquisition device.

\section{Data 4: wakul 'tempat nasi'}

Konfigurasi fonem pada leksikon wakul 'tempat nasi' adalah fonem /w/, /a/, /k/,/u/, dan /1/. Leksikon wakul memiliki urutan silabe penultima wa- dan ultima-kul. Konfigurasi yang diamati adalah konfigurasi yang terletak pada posisi ultima yakni konfigurasi fonem $/ k u l /$. Konfigurasi fonem $k$ - $u$-l ditengarai memiliki arti 'bulat'. Leksikon yang ditengarai memiliki silabe ultima - kul atau meminjam istilah yang digunakan Brandstetter adalah akar kata (Brandstetter 1957), maka leksikon tersebut memiliki arti yang semedan makna 'bulat', yakni pada leksikon, sebagai berikut.

a. wa-kul 'tempat nasi berbentuk bulat'

b. ba-kul 'tempat hasil bumi berbentuk bulat'

c. $t u-k u l$ 'sesuatu yang akan tumbuh ditandai dengan bentuk bulat terlebih dahulu'

d. rang-kul 'ada gerakan tangan yang membulat' 


\section{Simpulan}

Hasil penelitian konfigurasi fonem pada leksikon peralatan rumah tangga tradisional, menemukan kebaruan hasil penelitian, yakni:

a. Fonem secara otonom tidak memiliki arti hanya sebatas simbol bunyi yang bersifat kongkrit.

b. Fonem memiliki kemampuan membangun sebuah arti atau makna manakala mampu membangun sebuah konfigurasi fonem dengan fonem lain dalam sebuah kata.

c. Jumlah konfigurasi fonem tidak terbatas namun dikendalikan seperangkat laguage acquisition device.

d. Konfigurasi fonem dapat dipilahkan berdasarkan silabenya, melalui pemilahan silabe dapat ditemukan akar kata yang mempunyai potensi membangun kata baru yang semedan makna.

\section{Daftar Pustaka}

Antono, Arif, Ida Zulaeha, and Imam Baehaqie. 2019. "Pemertahanan Fonologis dan Leksikal Bahasa Jawa Di Kabupaten Wonogiri: Kajian Geografi Dialek." Jurnal Sastra Indonesia. Doi.org/10.15294/jsi.v8i1.29854.

Bergounioux, Gabriel. 2016. "L'invention de La Phonologie Entre Saussure et Le Cercle Linguistique de Prague.” Recherches Sémiotiques. Doi.org/10.7202/1037152ar.

Brandstetter, Renward. 1916. An Introduction to Indonesian Linguistics: Being Four Essay by Renward Brandstetter. Pertama. London: London Royal Asiatic Society.

—. 1957. Akar Kata Dan Kata Dalam Bahasa-Bahasa Indonesia. Pertama. Jakarta: PT Pustaka Rakyat.

Cairns, Charles E., N. S. Trubetzkoy, and Christiane A. M. Baltaxe. 1971. "Principles of Phonology.” Language. Doi.org/10.2307/412166.

Gani, Saida, and Berti Arsyad. 2019. "Kajian Teoritis Struktur Internal Bahasa (Fonologi, Morfologi, Sintaksis, Dan Semantik)." 'A Jamiy: Jurnal Bahasa dan Sastra Arab. Doi.org/10.31314/ajamiy.7.1.1-20.2018.

Haryati, Tri Astutik. 2017. "Kosmologi Jawa Sebagai Landasan Filosofis Etika Lingkungan." RELIGIA. https://doi.org/10.28918/religia.v20i2.1026.

"Karl Bühler et La Physionomie Acoustique Des Mots: Les Occasions Manqufies de La Phonologie.” 2012. Archivio Glottologico Italiano.

Santoso, Budi. 2017. "Bahasa dan Identitas Budaya." Sabda: Jurnal Kajian Kebudayaan. Doi.org/10.14710/sabda.v1i1.13266.

Sudaryanto. 1993. Metode dan Aneka Teknik Analisis Bahasa: Pengantar Penelitian Wahana Kebudayaan Secara Linguistis. yogyakarta: Duta Wacana University Press. 
Trager, George L., Benjamin Lee Whorf, and John B. Carroll. 1957. "Language, Thought, and Reality: Selected Writings of Benjamin Lee Whorf." Language. Doi.org/10.2307/411163.

Vachek, Josef. 2003. "Dictionary of the Prague School of Linguistics." Studies in Functional and Structural Linguistics. 